\title{
血圧と $\mathrm{EKG}$ と脂質との関連について (第一報)
}

○加藤恵美子* 市村 輝久* 根岸 清子* 後閑 﨣男* 笠原浩一郎**

くはじめに>事業所の集団検診において最も反複受診 率の高い農団健保組合を選んで，通常の検診項目（胃X 線, 血液 GOT, GPT, ALP, T. Cho, TG, BG, TP) 尿（A，G，Uro）血圧の他，血圧の正常者群の希望者 83 人（60人）境界者群 52 人（15人）異常者群 47 人（17 人)に対して EKG とコレステロール分画と $\beta$ リポを 加えてこれらのグループの年々の推位の追跡を試みた。 （）は女性。(受診者 1,200 人)

＜測定法＞コレステロールの分画はヘレナ社のセルロ ーズアセテート膜タイタン III HDL キットを用いて電 気泳動によって行った。分画定量值はデンシトメーター によって出た各分画\%に対して，T. Cho を乗じて各々 の定量值を求めた。電気泳動法と沈殿法との相関は諸家 の報告通りであった。 を用いた。

表はコレステロール中の HDL と LDL の比を年齢, 性, 血圧の分類については WHO の分類に従って各々 分類してその平均值を求めた。30歳台のサンプル数が男 女共に境界者群及び異常者群が 4 例と少なく, この点で の比較検討を行うことはできないが，次の所見を得た。 血圧の異常者群は男女共に加齢で HDL-C 量が減少し てくるため, その Atherogenetic index が増大して行 く傾向があった。又各々のヒストグラムにおいて非常に かけ離れた值は棄却したのでほぼ正規分布が得られた。

Decreased HDL-C 值を有するとされている High Risk (HDL-C $30 \mathrm{mg} / \mathrm{dl}$ 以下) を示したのは男 22 人で $11 \%$ ，女 14 人で $16 \%$ であった。これらのうち 5 人の
HDL-C は A : $7 \mathrm{mg} / \mathrm{dl}, \mathrm{B} \sim \mathrm{E}: 15 \sim 16 \mathrm{mg} / \mathrm{dl}$ であっ た。(紙面の都合で詳細な他の検查項目は省略。)

動脈硬化症に対する High Risk を有する症例に於て, $\mathrm{EKG}$, 肥満度, 糖尿病の有無などについて必ずしも現 時点で異常所見はなく, 動脈硬化の進展が証明されてい ない。今後これらの症例の追跡調査が必要と思われる。

$<\mathrm{EKG}$ の所見と HDL-C $>$ EKG の受診者男 196

人, 女86人であった。

\begin{tabular}{|c|c|c|c|}
\hline 平低T波 & $4(5)$ & 期外収縮 & $3(1)$ \\
\hline 尖鋭T波 & $1(0)$ & $\mathrm{QS}$ 型 $\mathrm{V}_{1} \sim \mathrm{V}_{3}$ & $1(0)$ \\
\hline $\mathrm{S} \mathrm{T}$ 上昇 & $1(0)$ & $\mathrm{I}$ 度 $\mathrm{AV}$ ブロック & $1(0)$ \\
\hline S T低下 & $3(3)$ & 高電位 & $2(1)$ \\
\hline 心房細動 & $1(0)$ & 一過性 WPW & $1(0)$ \\
\hline 完全右脚ブロック & $2(2)$ & 左軸偏位 & $5(1)$ \\
\hline 陰性 T波, 不完全 & & 左室肥大 & $22(2)$ \\
\hline 右脚ブロック & $1(0)$ & 計 & $51(16)$ \\
\hline $\mathrm{S}$ T 低下, 陰性 $\mathrm{T}$ & & ( ) : 女 & \\
\hline
\end{tabular}

波, 不完全右脚ブ 1(0)

ロック

この EKG 所見の中で Discreaseed HDL-C High Risk を示したものは男で $\mathrm{ST}$ 上昇 1 人, 平低 $\mathrm{T}$ 波 2 人, 尖鋭 $\mathrm{T}$ 波 1 人, 左軸偏位 1 人, 左室肥大 2 人で計 7 人。 女で ST 低下 2 人, 左軸偏位不完全右脚ブロック 1 人, 左室肥大 1 人で計 4 人であった。虚血性心疾患を示唆す るとされている ST 低下及び平低T波を示す症例が必 ずしも HDL-C に関して High Risk ではないことが

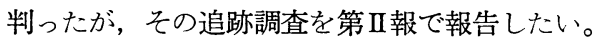

HDL-C \& LDL IN T. CHO

\begin{tabular}{|c|c|c|c|c|c|c|c|c|c|c|c|}
\hline & & \multirow{2}{*}{$\begin{array}{l}\mathrm{B} \cdot \mathbf{P} \\
\text { Age }\end{array}$} & \multicolumn{3}{|c|}{ Normal } & \multicolumn{3}{|c|}{ Boundary } & \multicolumn{3}{|c|}{ Abnormal } \\
\hline & & & $30 \sim$ & $40 \sim$ & $50 \sim$ & $30 \sim$ & $40 \sim$ & $50 \sim$ & $30 \sim$ & $40 \sim$ & $50 \sim$ \\
\hline \multirow{3}{*}{$M$} & & $\mathrm{~N}$ & 16 & 43 & 24 & 4 & 19 & 22 & 4 & 24 & 19 \\
\hline & \multirow{2}{*}{$\mathbf{x}:$} & Cho/HDL-C & 3.8 & 3.8 & 3.8 & 3.7 & 3.7 & 3.8 & 3.0 & 4.3 & 4.9 \\
\hline & & LDL/HDL-C & 2.6 & 2.4 & 2.4 & 2.3 & 2.3 & 2.6 & 2.0 & 2.8 & 3.1 \\
\hline \multirow{3}{*}{$\mathbf{F}$} & & $\mathrm{N}$ & 7 & 26 & 21 & 4 & 9 & 4 & 2 & 12 & 5 \\
\hline & \multirow{2}{*}{$\mathrm{x}:$} & Cho/HDL-C & 3.8 & 4.0 & 4.4 & 3.9 & 4.1 & 4.1 & 4.7 & 3.9 & 5.1 \\
\hline & & LDL/HDL-C & 2.6 & 2.0 & 3.0 & 2.1 & 3.3 & 3.2 & 3.5 & 2.6 & 3.9 \\
\hline
\end{tabular}

The relationship of lipid composition between B.P. and E.G.G.

* 三愛会群馬診療所 ** 群馬大学第二内科 